\title{
Література:
}

1. Urbanization: insights in a global megatrend. Governance and economy 2017-05-02. https://smartcityhub.com/governance-economy/urbanizationinsights-in-a-global-megatrend/ (дата обращения 08.11.2020).

2. Routley N. Charting the Last 20 Years of Supertall Skyscrapers. https://www.visualcapitalist.com/charting-the-last-20-years-of-supertallskyscrapers/(дата обращения 08.11.2020).

3. Ellis P.G., Torcellini P.A. SIMULATING TALL BUILDINGS USING ENERGYPLUS. Ninth International Building Performance Simulation Association (IBPSA) Conference and Exhibition (Building Simulation 2005), Montreal, Quebec, August 15-18, 2005.

4. Кривенко О.В. Задачи и направления применения природных аналогов при проектировании высотных биоклиматических зданий. «Архітектурний вісник КНУБА». - К.: КНУБА, 2019. - № 20. C. 337-342. DOI: $10.32347 / 2519-8661.2019-20.193601$

5. Krivenko O., Mileikovskyi V., Tkachenko T. The principles of energy efficient microclimate provision in the skyscraper «Biotecton» of $1 \mathrm{~km}$ height// European Journal of Formal Sciences and Engineering, ISSN 26018683, volume 1, Issue 3, 2018, p 8-17. http://dx.doi.org/10.26417/ ejef.v2i3.p66-75

DOI https://doi.org/10.30525/978-9934-26-004-9-108

\section{ЕВОЛЮЦІЯ МОТОРИЗОВАНИХ ТРАНСПОРТНИХ ЗАСОБІВ ЯК ГОЛОВНИЙ ЧИННИК ФОРМОУТВОРЕННЯ ОДЯГУ ВОДІЇВ}

\author{
Крічлоу К. В. \\ аспірант кафедри ергономіки і дизайну
}

Колосніченко О. В.

доктор мистеитвознавства, професор кафедри художнього моделювання костюма, Київського національного університету технологій та дизайну м. Київ, Украӥна

В сучасному житті одяг для водії моторизованих транспортних засобів МТЗ є явищем проектної культури, як і одяг будь-якої іншої сфери людського життя [1-2]. Стрімкий розвиток технологічного та культурного прогресу $€$ одним 3 факторів його популяризації та 
розповсюдження. Початком ери мото-індустрії можна вважати інженерні винаходи американця Сильвестра Говардо Ропера у 1867 році та німців Готліба Даймлера [3] і Вільгельма Майбаха [4] у 1885 році.

Це стало відправною точкою не лише у розвитку мототранспорту, а й започаткувало інший об'єкт дизайну - одяг для МТЗ. У історичному ракурсі ці напрями набули паралельної спрямованості та нерозривного зв'язку між собою, вони трансформувались та вдосконалювались під впливом художньо-естетичних традицій спираючись на інноваційні досягнення науки і техніки. Основні особливості етапів історичного розвитку МТЗ дозволяють нам стверджувати, що одяг водіїв $\epsilon$ їх своєрідним супутником та індикатором, що дозволяє виокремити та конкретизувати сферу застосування. Досліджуючи паралельний розвиток обох напрямів видно, що одяг водіїв перших мотоциклів відображав потреби мото-індустрії того часу. Першими в історії водіями були виключно заможні люди, а мотоцикли - були не стільки видом транспорту, скільки приводом продемонструвати свій статус в суспільстві. Правила етикету того часу вимагали від джентльмена презентабельного зовнішнього вигляду, i, оскільки твідові костюми були поширені як повсякденний одяг кінця вісімнадцятого століття, те ж саме вдягали i мотоциклісти. 3 часом мотоцикли вдосконалювались, покращувались показники швидкості та потужності, розширювались сфери їх застосування [5]. У 1990-х роках це сприяло виникненню таких напрямів, як МТЗ спортивного та спеціального призначення. Це одразу знайшло своє відображення у формуванні нових видів одягу.

В той самий час пристрасть до перегонів стала каталізатором розвитку спортивної мотоциклетної індустрії. Для досягнення збільшення швидкостей почали створювати не тільки мотоцикли, а й спеціальні траси. Так виникли перегони по колу на дерев'яних підмостках, серед яких найпоширенішим видом змагань були шосейні перегони на довгі дистанції. Для популяризації та більшої видовищності такі змагання почали проводитися на іподромах та велотреках, а згодом i на спеціальних мототреках, які були закриті від пішоходів і громадського транспорту [6]. У той же час, з'являються спеціальні випробування мотоциклів в змаганнях з підйому на пагорб і шосейно-лінійні перегони на встановлення рекорду швидкості. Виникнення нових видів змагань стимулювало створення спеціальних спортивних мотоциклів та відповідно до нових завдань, змінювався й одяг водіїв. 3 поширенням дорожніх перегонів перед дизайнерами та спортсменами постала задача досягнення максимальних швидкостей в рекордних заїздах на різні дистанції на прямих ділянках автострад та спеціальних треках. 
Конструкції мотоциклів мали відповідати вимогам маневреності i керованості на віражах, незважаючи на процес розгону і гальмування. Мото-спортсмени продовжували експериментувати та вигадувати нові змагання, деякі 3 них набули розвитку та популярності. Поєднання змагань на швидкість із бездоріжжям призвело до появи мото-кросових перегонів на пересіченій місцевості. Вперше такі змагання відбулись у 1908 році в Лондоні, як традиційні англійські перегони «перегони за лисом», де змагались кінні кавалеристи поруч з мотоциклістами.

Згодом, у 1913 році випробування мотто-техніки на складних-поганих дорогах були офіційно включені до перших щорічних шестиденних змагань - International Six Day Trial (ISDT). Пізніше ці змагання отримали назву «Ендуро». У 1930-і роки 3 поліпшенням якості трас та завдяки збільшенню швидкості спортивних мотоциклів, популярності набувають мотобол та трекові перегони. 3 часом набули популярності нові види спорту, пов'язані з мотоциклами, що взяли початок 3 розважальних програм та шоу та стали цілком самостійними видами спорту. Так, у 1970-х з'явилось фігурне водіння, у 1990-х стантрайдинг, мотофристайл та супер-мотто. 3 розвитком прогресу у машинобудуванні вдосконалювалися швидкість, маневреність зручність та надійність моделей мотоциклів разом з вдосконаленням спортивного одягу для водіїв. За специфікою мото-спортивних дисциплін одяг водіїв мав відповідати стилю керування - задовольняти потреби у ергономічності та безпеці. Естетичний вигляд спортивного одягу для водіїв набуває важливого місця як фірмовий стиль, зумовлений виразністю образу, завдяки кольоровому рішенню, структурі формоутворення, рекламних написів та логотипів.

Завдяки доступній ціні, швидкості і практичності, мотоцикли почали застосовувати у сферах спеціального призначення. Так $з$ 1900-х років мотоцикли активно використовувалися, поліцією, сільськими лікарями, листоношами i багатьма іншими категоріями працівників. Деякі мотоцикли розробляли спеціально для цих цілей. Ще до початку Першої світової війни, були представлені прототипи військових мотоциклів такими провідними компаніями як: Wilkinson Sword Company, що займалась виробництвом зброї для британської армії, Harley-Davidson та Indian Motorcycle, що запекло конкурували на ринку спортивних мотоциклів, Wanderery i NSU розроблені Німецькими інженерами. Вперше у великих масштабах мотоцикли використовувалися військами всіх сторін під час Першої світової війни 1914p. На мотоцикли встановлювали кулемети та застосовували як маневрений та швидкий транспорт для передачі повідомлень. Війська і підрозділи, створені після Першої світової війни, сприяли подальшому розвитку використання 
військових мотоциклів для тренувань. Німеччина після підписання Версальського договору [7] зосередилася на виробництві дорожніх i позашляхових мотоциклів 3 відповідними параметрами, 3 метою їх використання у військових операціях. Перед Другою світовою війною BMW представила кращі версії: R-51 i R-71, а в 1941 році фірма презентувала модель R-75 під назвою «Сахара». Цей мотоцикл легко проходив по піску, снігу або в горах. Ця модель була настільки добре спроектована, що згодом була розроблена копія BMW R-71, широко відома в СРСР як M-72 [8]. Друга світова війна збільшила попит на моторизовані транспортні засоби, що значно збільшило обсяги виробництва. Ті компанії, що втримались в продовж важких часів, наразі були повністю завантажені. Кожна 3 країн-учасниць військових дій використовувала власні виробництва: Великобританія-Royal Enfield, Norton i BSA, CССР-Урал, Італія-Moto Guzzi, Японія-Rikuo. Сполучені Штати Америки-Harley Davidson, Німеччина-BMW i Zündapp.

По закінченню другої світової війни тривали потужні соціальні зрушення, процеси конверсії сприяли активному застосуванню елементів військових моторизованих транспортних засобів та спецодягу. Це стало підгрунтям для виникнення багатьох субкультур, та, як наслідок формування нового напряму розвитку застосування МТЗ. Одяг представників субкультур починає розвиватися в залежності від поглядів, смаків та переконань його послідовників та у відповідності до технічного прогресу, що відбувається у мотоіндустрії. Так, у повоєнному світі почали виникати субкультури, що об'єднували певні групи людей й базувалися на особливій філософії життя та пристрасті до мотоіндустії. Спочатку у Сполучених Штатах Америки у 1940-х роках виникли «Байкери», згодом, у Великій Британії у 1950-х роках - «Рокери» та «Моди» [9]. Під хвилею популярності японських коміксів та фільму “Зоряні війни” у 1980-х роках набрала популярності субкультура «ПаверРейнджерів»; «Хіпстери» та «Сіті-драйвери» виникли у 2000-х [10].

3 усього вище зазначеного видно, що різні сфери використання моторизованих транспортних засобів вимагали відповідного одягу, який поступово набував власних стильових характеристик та був нерозривно пов'язаний із розвитком моторизованих транспортних засобів. Тривалий час питанню зовнішнього вигляду одягу водіїв мотоциклів не приділялася належна увага, оскільки вважалось, що функція, надійність, довговічність матеріалів та зручність користування - $\epsilon$ першочерговими. Проте сучасні дослідження доводять, що одяг належить до не вербального засобу сприйняття, який є джерелом 97\% візуальної інформації. Таким чином, спираючись на проведене історіографічне 
дослідження, можна стверджувати, одяг водіїв моторизованих транспортних засобів є багатогранним явищем проектної культури, що знаходиться у процесі постійного удосконалення та потребує глибокого дослідження.

\section{Лiтература:}

1. M. V. Kolosnichenko, K. L. Pashkevich, T. F. Krotova et al. Fashion design in a multicultural space. Monograph. - Kyiv: KNUTD. 2020. Publisched by Academic Society of Michal Baludansky, Košice, Slovakia, 2020. $-258 \mathrm{p}$.

2. Колосніченко О. В. Формоутворення одягу спеціального призначення як об’єкта дизайн-діяльності. Монографія. - Київ: КНУТД. 2018. $-420 \mathrm{c}$.

3. T. Krens, M. Drutt, M. Guggenheim. Catalogue Of Exhibiotin: Guggenheim Museum. 1998. - 427p. ISBN-13: 978-0-89207-207-1, ISBN: 0-89207-207-5

4. Konrad Reif. Gasoline Engine Management. Systems and Components: Springer Fachmedien Wiesbaden. 2014. - 354 c. ISBN: 9783658039646

5. Maher, Kevin \& Greisler, Ben. Chilton's Motorcycle Handbook. North America: Cengage Learning. 1998. - 500 c. ISBN: 0-8019-9099-8

6. Бекман В. В. Гоночные мотоциклы. Ленинград: МАШГИЗ. 1961. $169 \mathrm{c}$

7. [BMW - Wikipedia, The Free Encyclopedia. Електронний ресурс. URL: https://dokumen.tips/documents/bmw-wikipedia-the-freeencyclopedia.html (дата звернення 20.10.2020).

8. Постановление СНК СССР и ВКП(б) № 456 - от 04.03.1941. «О развитии производства мотоциклов в СССР». 1941. - 189 с.

9. Garson P. Born to Be Wild. A History of the American Biker and Bikes 1947-2002. Mobipocket_Ebook: Editors Of Easyriders. Simon \& Schuster. 2007. -320 p. ISBN-13: 978-1-4165-7523-8, ISBN: 1-4165-7523-5

10. Мотоэкипировка: виды и назначений. Електронний ресурс. Дата оновлення 11.03.2020. URL: https://www.webike.com.ru/news/ motoekipirovka-vidy-i-naznacheniya/ (дата звернення 20.10.2020). 